\title{
The influence of higher speed limits on motorways on road safety and truck accidents
}

\author{
P. De Winne $\mathrm{e}^{1,2}$ \& E. De Winne ${ }^{1,3}$ \\ ${ }^{I}$ Faculty of Engineering Sciences, Department Civil Techniques, \\ Ghent University, Belgium \\ ${ }^{2}$ Road and Traffic Agency, Road Engineering Division, \\ Flemish Ministry of Mobility and Public Works, Belgium \\ ${ }^{3}$ Department of Mobility and Public Works, \\ Flemish Ministry of Mobility and Public Works, Belgium
}

\begin{abstract}
In order to determine the maximum speed limit, first an optimal balance must be determined between the benefits in terms of mobility and the impact on road safety. Amateurs of increasing the speed limit on motorways to $130 \mathrm{~km} / \mathrm{h}$ base themselves on international comparisons and on the fact that vehicles today are equipped with active and passive safety technology. But one can not ignore the fact that a higher speed limit on motorways is likely to have a negative impact on road safety.

The paper describes the relationship between the "higher" speed and the impact on the number of accidents and their gravity, on the speed differences and on the impact on mobility in general. Because accidents involving trucks are so spectacular, they remain often etched in memory. With their imposing mass, these vehicles often increase the impact of an accident and also the impact on mobility is correspondingly. From the statistics, a number of important conclusions can be drawn regarding the risk assessment for truck accidents, the death risk to the occupants in the truck or other vehicles involved, the severity of the truck accidents, the proportion of truck accidents on the motorways, the types of accidents, and the distribution of truck accidents by day and night.
\end{abstract}

Keywords: speed limit, traffic safety, truck accidents. 


\section{Introduction}

A road speed limit is the maximum speed allowed by law for road vehicles. The first maximum speed limit was the 10 miles per hour $(16.1 \mathrm{~km} / \mathrm{h})$ limit introduced in the United Kingdom in 1861 by the Locomotive Act (automobiles were in those days termed "light locomotives"). Today, in most countries, speed limits are commonly set and enforced by the legislative bodies of nations or provincial governments. However, there are some places with exceptional rules: the Isle of Man is the only place in the world that does not have a general speed limit and in Germany, 57\% of the motorways remains free from speed limits [1].

Increasing the speed limit on motorways, generally leads to higher speeds and more accidents. The change in speed is roughly one-fourth the change in speed limit. Most of the speed related crashes involve speed too fast for conditions. This would suggest that variable speed limits that adjust with traffic and environmental conditions could provide potential benefits. When an accident occurs, its severity depends on the change in speed of the vehicle at impact. The fatality risk increases with the change in speed to the fourth power [2].

\section{The maximum speed limit on Belgian motorways}

In the 1970s we had in Belgium more than 3000 fatalities per year. In 1973, a year after a sad historical record was reached (3101 fatalities), speed restrictions were introduced as a result of the oil crisis. In 1974, the limit of $120 \mathrm{~km} / \mathrm{h}$ on motorways and $90 \mathrm{~km} / \mathrm{h}$ on other roads finally introduced. This was the beginning of a whole series of measures that significantly improved the traffic situation. In 1984, the death rate for the first time again lower than 2000 and in 1995 this figure had fallen to less than 1500.

Since the $70 \mathrm{~s}$, road safety has strongly improved. The annual number of deaths 30 days [ = a fatal injury which causes death less than 30 days after the accident] is three times smaller. The number of serious injuries in that time period became four times smaller. This positive evolution is even more remarkable because the number of vehicles in this period is doubled and three times as many kilometres were travelled. Thus, the fatality risk per kilometre travelled is almost nine times smaller.

Today, the maximum speed limit on the Belgian motorway is $120 \mathrm{~km} / \mathrm{h}$. Trucks are limited to $90 \mathrm{~km} / \mathrm{h}$. Increasing the maximum speed limit has an effect on the number of accidents and the severity of the accidents.

A higher maximum speed limit leads to a greater range of speeds, so higher speed differences between different vehicles, which increases the number of accidents rapidly. Results from international studies suggest that for every 1 $\mathrm{km} / \mathrm{h}$ change in speed, injury accidents will change by 3 percent ( 5 percent for every $1 \mathrm{mi} / \mathrm{h}$ ) [2].

The higher the speed, the larger the released forces, so even more severe the accident. The accident risk is the lowest on the highway, but in the event an accident occurs, it is immediately very severe. Today we count 41 deaths per 100 injury accidents on motorways. On all types of roads together, this figure is on 
average only 27 . This means that the severity of accidents on motorways is much larger.

Belgium set clear targets: by 2010, the number of deaths on the Belgian roads should be maximum 750 ; by 2015 , this number should be maximum 500 . Between 2000 and 2006 the number of deaths in Belgium decreased by $26.6 \%$ (from about 1500 to 1069). Today, in 2009, we see that the decrease in the number of deaths continues. The annual total for the month of January 2009 was 828 deaths, while the annual total of January 2008 was still 968 . For the amount of injury accidents and the number of injured road victims, there is a different conclusion, as we observe only a slight decrease setting between January 2009 and January 2008 ( $-2.0 \%$ for the amount of injury accidents and $-2.2 \%$ for the number of injured road victims). In comparison with the beginning of 2005 we see only a minimal decline, which means the amount of injury accidents per year still varies around $50000[3,4]$.

\section{Speed on the European motorways}

International comparisons show that Belgium is one of the European pioneers that achieved the largest decline in the number of deaths 30 days. Despite these positive developments, Belgium is still behind if we make the comparison based on the number of deaths 30 days per 100000 inhabitants (10.2 in 2006) or per billion vehicle kilometres travelled (11.1 in 2006). By comparison, the Netherlands has 4.5 deaths per 100,000 inhabitants, France 7.7 and Germany 6.2.

The speed limit on motorways is generally 110,120 or $130 \mathrm{~km} / \mathrm{h}$. Below is a table giving general maximum speed limits for cars and trucks. In some countries limits are reduced in bad weather conditions or for newly qualified drivers.

Speed limits for trucks vary greatly between the different countries in Europe. The table below shows the current speed limits for trucks up to $40 \mathrm{t}$ in the most important European countries [5, 6].

\section{Impact of maximum speeds on travel times, emissions and road safety}

\subsection{Impact on safety: how to calculate?}

What impact does the change of speed limit have on road safety, considering the other influencing factors remain the same? When comparing the experiences from several countries, we almost always experience a link between speed and accident rate. For example, France says two thirds of the reduction of the death figure is a result of the more frequent speed control on the road by police forces. Also on Swiss motorways, the number of deaths is reduced by $12 \%$, thanks to the reduction of the maximum speed of 130 to $120 \mathrm{~km} / \mathrm{h}$ in 1985 [7].

In Germany people want more and more, the introduction of a maximum speed on motorways. Today $57 \%$ of German motorways have no speed limit (there is only a recommended target speed of $130 \mathrm{~km} / \mathrm{h}$ ). On about $15 \%$ of the motorways, a temporary speed limit because of special circumstances (eg road- 
Table 1: $\quad$ Speed limits in Europe $(\mathrm{km} / \mathrm{h})$.

\begin{tabular}{|c|c|c|}
\hline Country & $\begin{array}{c}\text { General speed limit on } \\
\text { Motorways (cars) }\end{array}$ & $\begin{array}{l}\text { Speed Limit on Motorways } \\
\text { (trucks) }\end{array}$ \\
\hline Austria & 130 & 80 \\
\hline Belgium & 120 & 90 \\
\hline Bulgaria & 120 & 100 \\
\hline Cyprus & 100 & 100 \\
\hline Czech Republic & 130 & 80 \\
\hline Denmark & 110 & 80 \\
\hline Estonia & no motorways & - \\
\hline Finland & 120 & 80 \\
\hline France & 130 & 90 \\
\hline Germany & $\begin{array}{l}\text { no limit (130 } \\
\text { recommended) }\end{array}$ & 80 \\
\hline Greece & 120 & 90 (70 for truck+trailer) \\
\hline Hungary & 130 & 80 \\
\hline Ireland & 120 & 80 \\
\hline Italy & 130 & $100(80$ for trucks $>12 t)$ \\
\hline Latvia & 130 & $90(80$ for trucks $>7.5 t)$ \\
\hline Lithuania & no motorways & - \\
\hline Luxembourg & 130 & 90 \\
\hline Malta & no motorways & - \\
\hline Poland & 130 & 80 \\
\hline Portugal & 120 & 90 (80 for truck+trailer) \\
\hline Romania & 130 & $110(90$ for trucks $>7.5 t)$ \\
\hline Slovakia & 130 & 80 \\
\hline Slovenia & 130 & 80 \\
\hline Spain & 120 & 90 \\
\hline Sweden & 110 & 80 \\
\hline Switzerland & 120 & 80 \\
\hline The Netherlands & 120 & 80 \\
\hline United Kingdom & $112(70 \mathrm{mph})$ & $96(64$ for truck +2 trailers \\
\hline
\end{tabular}

works), only $33 \%$ of the motorways has a permanent speed restriction. Of the 645 fatal injuries on German motorways in 2006, there were 441 (or 67\%) on motorways without speed limit. A comparison of the situation before and after in places where the speed limit was introduced, is a strong argument for the introduction of a speed limit. After all, we systematically notice a significant reduction in the number of deaths and injuries. For example, the introduction of a maximum speed of $130 \mathrm{~km} / \mathrm{h}$ over a distance of $62 \mathrm{~km}$ between Berlin and Hamburg immediately resulted in a decrease by $48 \%$ of the number of injury 
accidents and there were $57 \%$ less injured road victims. Various experiments on other sections of the motorway network had a similar effect.

A way to examine the relationship between vehicle speed and traffic safety is to measure the effects of lowering or raising speed limits on the incidence and severity of crashes. Figure 1 summarizes the results of studies of this type conducted in several countries. It shows that crash-incidence or crash severity, or both measures, generally decline whenever speed limits have been reduced. Conversely, the number of crashes or crash severity generally increased when speed limits were raised, especially on motorways [2].

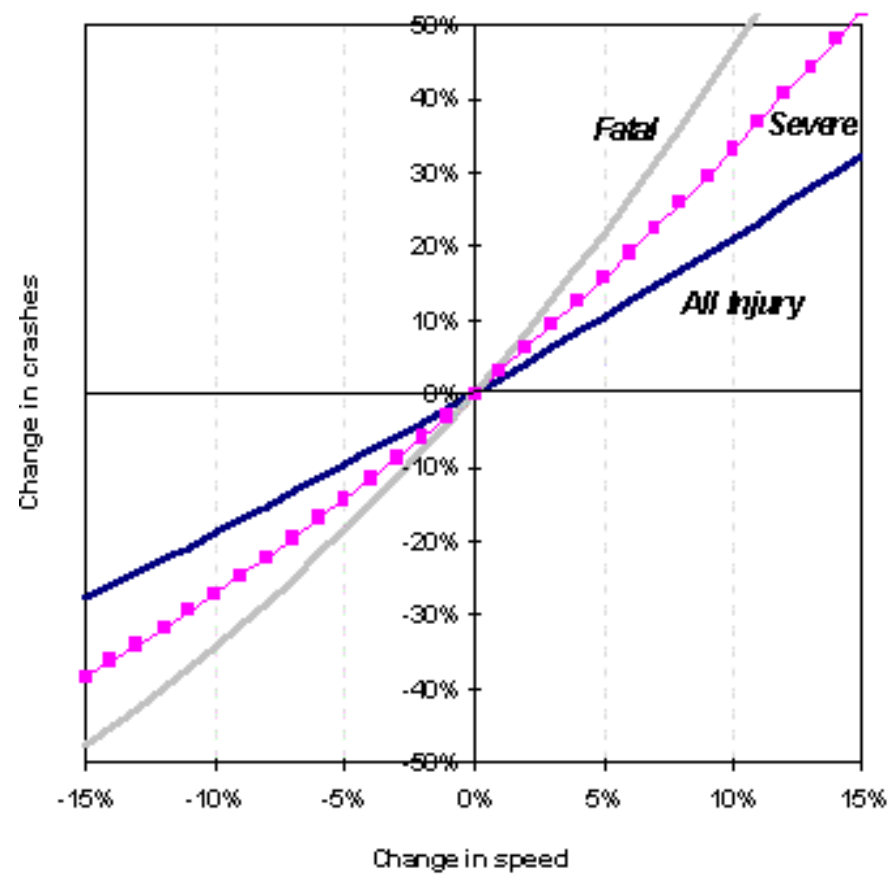

Figure 1: $\quad$ Effects of changes in the speed on injury and fatal crashes (from Nilsson, 1981).

Another way to evaluate the effect of vehicle speed on traffic safety is by calculation using the "Power model" [8-10].

For the calculation of the effects of a change in speed limit we rely on an adapted version of the "Power model" as developed by Nilsson. This model suggests that the impact of the change in speed on the number of accidents and severity of accidents can be estimated on the basis of power functions. The Power model describes the relationship between speed and safety by using the following equations. 


$$
\begin{aligned}
& \frac{(\text { number of fatal accidents }) \text { after }}{(\text { number of fatal accidents }) \text { before }}=\left(\frac{\text { speed after }}{\text { speed before }}\right)^{3,6} \\
& \frac{(\text { number of serious injury accidents }) \text { after }}{(\text { number of serious injury accidents }) \text { before }}=\left(\frac{\text { speed after }}{\text { speed before }}\right)^{2} \\
& \frac{(\text { number of slight injury accidents }) \text { after }}{(\text { number of slight injury accidents }) \text { before }}=\left(\frac{\text { speed after }}{\text { speed before }}\right)^{1,1} \\
& \frac{(\text { number of accidents with only damage)after }}{(\text { number of accidents with only damage)before }}=\left(\frac{\text { speed after }}{\text { speed before }}\right)^{1}
\end{aligned}
$$

This model is widely spread to estimate the expected impact on accidents and has been the subject of a number of meta-analysis. The "Power model" is a simple model, because it does not take into account the traffic congestion, the variation in speed, the proportion of trucks,... Despite its simplicity there is much empirical support for this model.

\subsection{Impact on mobility and environment.}

As for the mobility, we can not guarantee that a higher speed limit would save time for drivers. Most drivers estimate the time saved by speeding usually higher than in fact the case.

The traffic flow is even better at lower speeds, just think of the block movement with a speed of $80 \mathrm{~km} / \mathrm{h}$ to resolve the holiday traffic jams to the Belgian coast. Even for a relatively long distance of $100 \mathrm{~km}$, you win with a speed of $130 \mathrm{~km} / \mathrm{h}$ instead of $120 \mathrm{~km} / \mathrm{h}$ only 3 minutes and 50 seconds, provided that the traffic conditions are ideal. This is rarely the case, and the additional accidents due to higher traffic speeds will only increase. The economic profit by considering the shorter travel time does not outweigh the loss due to the higher number of accidents [7].

Environmentally, higher speeds make that the fuel consumption increase, as a result of which the polluting emission increases. This goes so directly against the need to reduce $\mathrm{CO} 2$ emissions, such as determined by the European directives.

\subsection{Results for Belgium}

The report [13] describes the results of a small study to estimate the effects of a change in maximum allowed speed on motorways in Belgium. The study has only considered passenger transport, so the results apply only to that category of road users. The study looked at the effects on travel times, emissions of PM10, NOx and $\mathrm{CO}_{2}$, and on traffic safety. Three variants were studied: a change in maximum speed for passenger cars from $120 \mathrm{~km} / \mathrm{h}$ to $100 \mathrm{~km} / \mathrm{h}$, to $110 \mathrm{~km} / \mathrm{h}$ and to $130 \mathrm{~km} / \mathrm{h}$. 
In a fist step, the effect of a change in maximum speed on actual speeds on the roads was estimated. Measurements of traffic on Belgian motorways in 2007 were used. Based on traffic flow theory, the effect on speed was estimated for each data point. Then the effects on travel times, emissions and traffic safety were estimated, based on these changed data points.

Regarding the calculation of costs for road safety, they made use of the following statistics for year 2007 (considering only the Belgian motorways) [12]:

- number of fatal accidents: 3931

- number of fatal injuries (death 30 days): 153

- number of serious injuries: 1053

- number of slight injuries: 4637

The actual cost of road accidents is estimated as follows [11]:

$$
\sum_{i}\left(r_{i} * k_{i} * v k m\right)
$$

With:

i: the road accident type: fatal, serious injury, slight injury, or only damage

$r_{i}$ : the risk of accident type i per vehicle kilometre

$\mathrm{k}_{\mathrm{i}}$ : the cost of road accident type $\mathrm{i}$

$v k m$ : the amount of vehicle kilometres (Notice: $r_{i}{ }^{*} \mathrm{vkm}$ is equal to the number of accidents type i).

For $\mathrm{k}_{\mathrm{i}}$ to calculate - and thus the effect of a speed reduction on the cost of accidents to know - we need to determine the cost of an accident. The cost of an accident $\left(\mathrm{k}_{\mathrm{i}}\right)$ can be divided into:

- direct economic costs: medical costs, legal costs, property costs, ...;

- indirect economic costs: lost production for the economy because someone dies or the inability to work more/less by the accident;

- value of security is the value that people attach to their life - measured by 'value of a statistical life'.

Following values for Belgium (in 2008 prices) are recommended [11]:

Table 2: $\quad$ Cost (Euro) of an accident in 2008 according to Bickel [11, 13].

\begin{tabular}{|l|r|r|r|}
\hline & \multicolumn{1}{|c|}{ fatality } & serious injury & slight injury \\
\hline value of a statistical life & 1.653 .830 & 215.331 & 16.538 \\
\hline direct en indirect economic costs & 165.383 & 61.047 & 1.221 \\
\hline Total (Euro) & 1.819 .213 & 276.378 & 17.759 \\
\hline
\end{tabular}

We now have all the elements to calculate the cost of all accidents. When the risk - or the total number of accidents - is changing (as a result of changing the speed, by using the Power model) we can calculate the change in accident cost.

The results for Belgium can be found in the table 3 below. This table indicates the difference in costs and benefits, compared with the reference situation (a maximum speed of $120 \mathrm{~km} / \mathrm{h}$ ). Negative figures show a decrease of costs, positive figures an increase. Note that only passenger car transport is considered. 
Table 3: Difference in costs and benefits (in million Euro/year), compared with the reference situation $(120 \mathrm{~km} / \mathrm{h})$.

\begin{tabular}{|l|c|c|c|}
\hline & $100 \mathrm{~km} / \mathrm{h}$ & $110 \mathrm{~km} / \mathrm{h}$ & $130 \mathrm{~km} / \mathrm{h}$ \\
\hline Travel time & 254 & 104 & -84 \\
\hline NOx & -3.26 & -1.75 & 2.04 \\
$\mathrm{PM}$ & -58.73 & -29.95 & 32.81 \\
$\mathrm{CO}_{2}$ & -7.35 & -3.93 & 4.55 \\
\hline Road safety & -217 & -105 & 107 \\
\hline Total & -32 & -36 & 62 \\
\hline
\end{tabular}

Combining travel times, emissions and road safety, a reduction of the speed limit to $110 \mathrm{~km} / \mathrm{h}$ gives the most benefits: a reduction of the costs to society with 36 million Euro/year. Due to the high costs of the increased travel times, lowering the maximum speed towards $100 \mathrm{~km} / \mathrm{h}$ gives a smaller benefit than one would achieve with $110 \mathrm{~km} / \mathrm{h}$. Increasing the speed limit to $130 \mathrm{~km} / \mathrm{h}$ leads to negative effects: the travel time costs reduce, but the emissions and road safety costs increase largely [13].

\section{Truck accidents in Belgium}

\subsection{Evolution of the number of accidents involving trucks}

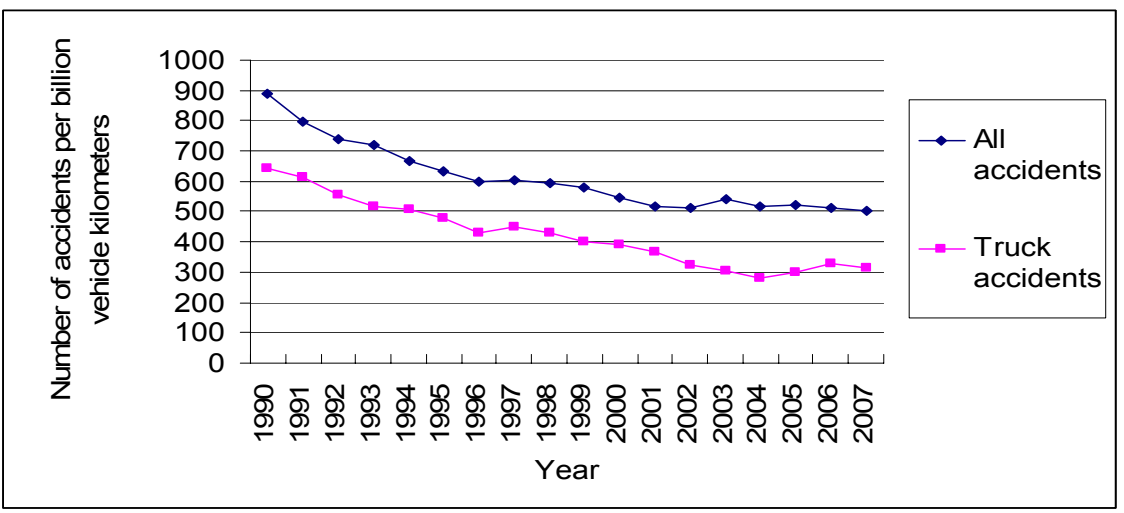

Figure 2: $\quad$ Evolution of the number of accidents per billion vehicle kilometres travelled for a) trucks and b) all users together [12, 14-16].

Figure 2 shows that the risk of accidents per billion vehicle kilometres travelled for trucks is not higher than for other road users. Rather, this risk is even $30 \%$ lower for trucks than when we consider all vehicles together. Also note that this figure is declining less rapidly since 2003 [14]. 


\subsection{Death risk per billion vehicle kilometres travelled}

If we consider all vehicle categories, we counted in 2008 just above 10 deaths per billion vehicle kilometres. In accidents involving trucks there were fifteen.

The number of death (30 days) is the most reliable indicator because the information about the number of death on the spot, gathered by the police, is added to the number of fatal injuries who died in the hospital within 30 days after the accident, which is gathered by the notification of the prosecutor [14].

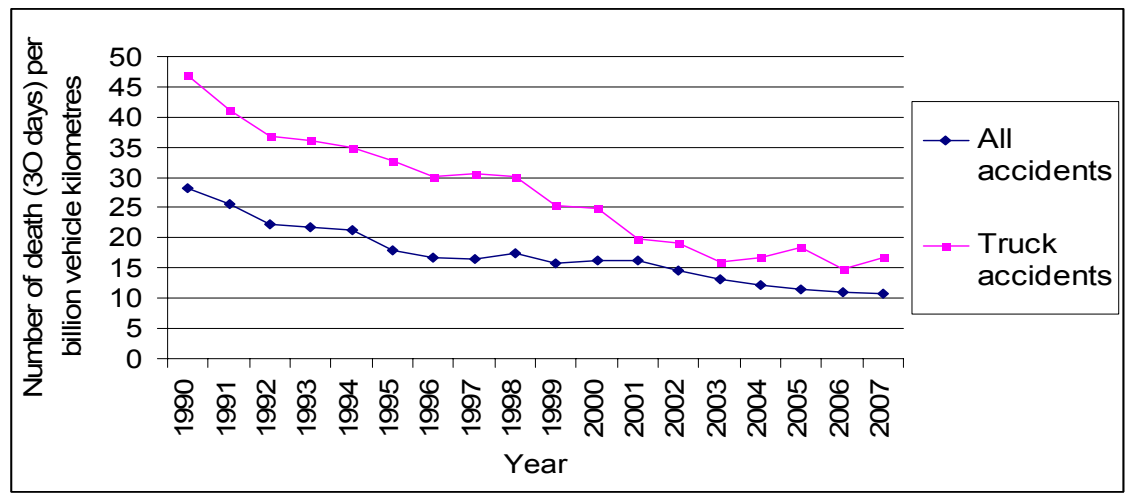

Figure 3: Evolution of the number of death per billion vehicle kilometres travelled for a) trucks and b) all users together [3, 12, 14, 16].

\subsection{Evolution of the severity of accidents involving trucks}

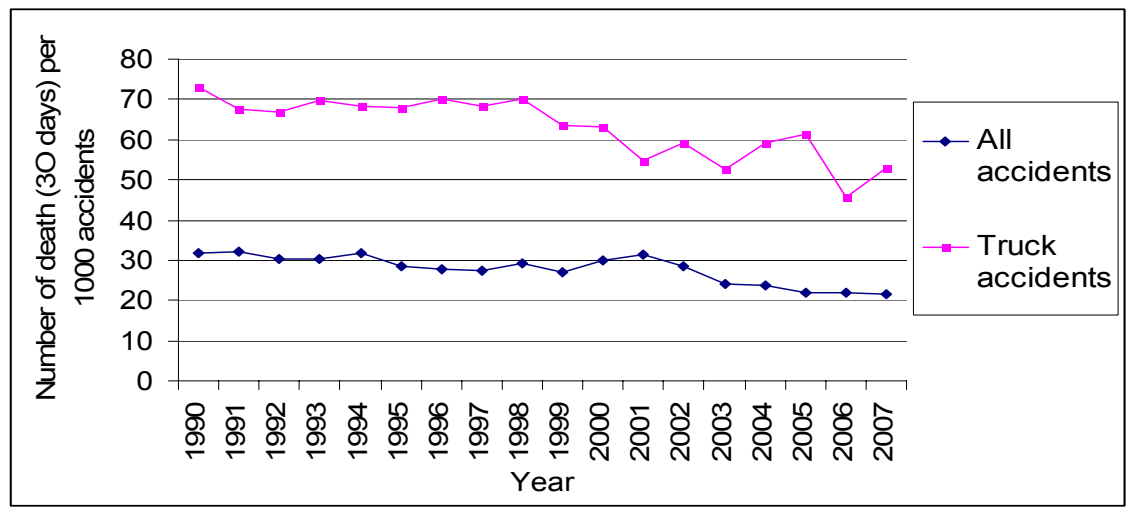

Figure 4: Evolution of the severity of accidents involving trucks: the number of death per 1000 injury accidents $[3,12,14,16]$.

Accidents involving trucks occur less common, although the damage is even greater. By 1000 injury accidents in the Belgian traffic in 2007, we have just over 20 deaths, but if we only look at accidents involving trucks, the death toll is 
about 55. Accidents involving trucks are twice as severe, so they are so wide spread in the media. In the nineties, the severity of truck accidents varied between 60 and 70 deaths per 1000 accidents since the turn of the century we have values between 50 and 60 [14].

\section{Truck accidents on Belgian motorways}

\subsection{There are more accidents involving trucks on motorways}

$7.7 \%$ of all accidents occur on the motorways, but this figure rises to $31 \%$ when we only consider the truck accidents. $43 \%$ of fatal and serious injuries involving truck accidents are on the motorway.

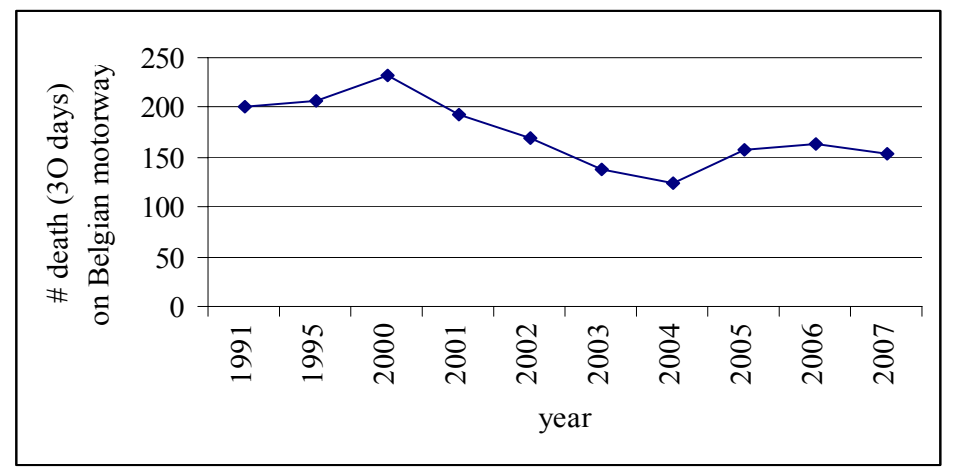

Figure 5: Number of deaths 30 days on Belgian motorways [12, 14].

Almost one third of the truck accidents occur on the motorways, only one fourth will take place in urban areas.

Table 4: $\quad$ Percentage of deaths (30 days) in accidents with at least one truck involved and the proportion of trucks in the Belgian motorway traffic in year 2006 .

\begin{tabular}{|l|c|c|}
\hline & Walloon Region & Flemish Region \\
\hline $\begin{array}{l}\text { \% of deaths with at least } \\
\text { one truck involved }\end{array}$ & $15.9 \%$ & $39.7 \%$ \\
\hline $\begin{array}{l}\% \text { of vehicle kilometres } \\
\text { travelled by trucks }\end{array}$ & $15.6 \%$ & $17.4 \%$ \\
\hline
\end{tabular}

Typical for the Flemish Region, the problem of accidents involving trucks on motorways: $39.7 \%$ of the fatalities in year 2006 happened in an accident with at least one truck, while trucks had only a share of $17.4 \%$ in the number of vehicle kilometres on motorways [4, 14]. 


\subsection{Rear-end collisions on motorways, side collisions and rear-end collisions on other roads}

The nature of the collisions involving trucks depends on whether the accident may or may not occur on the motorway. On the motorway we see primarily rearend collisions (due to the non-observance of speed limits and safety distances), while other roads are mainly lateral collisions (caused by poor visibility) and rear-end collisions $[4,12,14]$.

\subsection{The vast majority of accidents involving trucks occur during the day and week}

The Belgian figures show that, as expected, only $10 \%$ of the injury accidents with heavy trucks involved happen during the weekend (Saturday + Sunday). The figures show that, of all injury accidents during the week days, there are $86 \%$ between $6.00 \mathrm{~h}$. and $20.00 \mathrm{~h}$ and $14 \%$ in the evening and night; there are no pronounced peak times within this period $[4,12,14]$.

\section{Conclusions}

In order to achieve the Belgian objectives (by 2010, the number of deaths on the Belgian roads should be maximum 750 , by 2015 , this number should be maximum 500) posting an appropriate maximum speed on motorways can be a good measure. The calculations show that a reduction of the maximum speed of $120 \mathrm{~km} / \mathrm{h}$ to $110 \mathrm{~km} / \mathrm{h}$, regarding travel time, emissions and road safety, gives the greatest benefits when only passenger car traffic is considered. Lowering the maximum speed limit on Belgian motorways for trucks to $80 \mathrm{~km} / \mathrm{h}$ or less should be further investigated. However, today there is a speed difference of $30 \mathrm{~km} / \mathrm{h}$ (120 minus 90) between passenger cars and trucks, which perhaps could be preserved.

We must however note that in general the speed limits on the Belgian roads are often not respected. The violation rate (from more than $1 \mathrm{~km} / \mathrm{h}$ too fast) remains high for all speed regimes. In the Flemish Region, we note since 2005 no further progress. Speed measurements show that, in all speed regimes, during the night people drive faster than during daytime. This would suggest that variable speed limits that adjust with traffic and environmental conditions could provide potential benefits.

Policy measures aimed at reducing the speed are necessary. The more the average speed decreases the greater the number of lives being saved.

\section{References}

[1] WIKIPEDIA, http://en.wikipedia.org/wiki/Speed_limit

[2] U.S. Federal Highway Administration, Synthesis of Safety Research Related to Speed and Speed Limits, FHWA-RD-98-154, 1998, http://www.tfhrc.gov/safety/speed/speed.htm 
[3] Belgisch Instituut voor de Verkeersveiligheid vzw, Lokale Politie, Federale Politie, Verkeersveiligheidsbarometer januari 2009, pp. 1-26, 2009.

[4] Casteels Y., Scheers M., Belgisch Instituut voor de Verkeersveiligheid vzw, Observatorium voor de verkeersveiligheid, Evolutie van de verkeersveiligheid in België 2000 - 2006, D/2008/0779/70, Brussel, 2008.

[5] International Road Transport Union, IRU, Speed limits in Europe, http://www.man-truckers-world.co.uk

[6] European Tourist Office, ETO, Driving in Europe: Speed limits, http://www.europe.org/speedlimits.html

[7] Godart B., Hogere maximumsnelheid op de autosnelweg is verkeersonveilig, Via Secura nr. 77, pp. 8-11, 2008.

[8] Elvik. R, Speed, speed camera's and road safety evaluation research, A presentation given to the Royal Statistical Society, November 10, 2004.

[9] Elvik R., Vaa T., Handbook of Road Safety Measures, Elsevier, 2005.

[10] Aarts, L., van Schagen I., Driving speed and the risk of road crashes: a review, Accident Analysis and Prevention, 38(2), pp. 215-224, 2006.

[11] Bickel P., et al., HEATCO deliverable 5, Proposal for harmonised guidelines, Developing harmonised European Approaches for transport costing and project assessment, Institut für Energiewissenschaft und Rationelle Energieanwendung, Stuttgart, EU- SIXTH FRAMEWORK PROGRAMME $2002-2006$.

[12] FOD Economie, KMO, Middenstand en Energie - Algemene Directie Statistiek en Economische Informatie, http://statbel.fgov.be

[13] Vanhove F., Transport and Mobility Leuven, Impact van maximumsnelheid op autosnelwegen, Rapport in opdracht van Bond Beter Leefmilieu, January 2009.

[14] Casteels Y., Godart B., Vrachtwagenongevallen onder de loep, Via Secura nr. 78, pp. 8-11, 2008.

[15] Meersman H., Van de Voorde E., Vanelslander T. Verberght E., Het Vlaams Indicatorenboek Duurzaam Goederenvervoer 2007, Universiteit Antwerpen, Rapport in opdracht van Vlaams Minister-President Kris Peeters, D/2008/11528/1, pp. 61-62, 2008.

[16] Federale Overheidsdienst Mobiliteit en Vervoer, Verkeerstellingen 2007, deel IV, Tellingen betreffende het zwaar vervoer, pp. 63-66, November 2008. 